\title{
Menjaga Kesehatan Mental Keluarga saat Pembatasan Sosial Berskala Besar pada Masa Pandemi Covid-19
}

\author{
Dian Furwasyih $^{1}$, Sunesni ${ }^{2}$, Yulia Arifin ${ }^{3}$, Rahmayeni Supri ${ }^{4}$, Widya Zalmawita ${ }^{5}$, \\ Miftah Dwi Riska ${ }^{6}$ \\ E mail: deemidwife@gmail.com \\ Program Studi Kebidanan, Program Sarjana dan Pendidikan, Profesi Bidan, Program Profesi \\ STIKes Mercubaktijaya Padang, Indonesia \\ Jalan Jamal Jamil Pondok Kopi Siteba Padang \\ Telp/Fax. (0751) 442295
}

\begin{abstract}
Abstrak
Wabah infeksi virus coronavirus COVID-19 yang telah menyebar ke suluruh dunia sangat berdampak pada kesehatan masyakat dunia, termasuk kesehatan mental. Stress yang muncul selama masa pandemi COVID-19 dapat berupa ketakutan dan kecemasan mengenai kesehatan diri maupun kesehatan orang lain yang disayangi, perubahan pola tidur dan pola makan, memperparah kondisi fisik terutama pada seseorang dengan penyakit kronis. Kegiatan pengabdian kepada masyarakat (abdimas) ini merupakan salah satu solusi yang diharapkan dapat menambah wawasan audiens tentang menjaga kesehatan mental keluarga di masa pandemi COVID-19. Kegiatan ini dilaksanakan melalui media CISCO WEBEX Meeting. Luaran dari kegiatan ini adalah meningkatkan pengetahuan audiens tentang kesehatan mental sebesar 37.5\%, publikasi kegiatan di media youtube dan artikel publikasi di jurnal pengabdian masyarakat.
\end{abstract}

Kata Kunci: kesehatan mental; PSBB; pandemi COVID-19

\begin{abstract}
The outbreak of the COVID-19 coronavirus infection that has spread throughout the world has had a major impact on the health of the global community, including mental health. Stress that arises during the COVID-19 pandemic could be in the form of fear and anxiety about personal health and the health of other loved ones, changes in sleep and diet patterns, aggravating physical conditions, especially in someone with chronic illness. This activity is one solution that is expected to broaden the audience's insight about maintaining the mental health of families during the COVID-19 pandemic. This activity is carried out through CISCO WEBEX Meeting media. The outputof this activity was the increase of level of knowledge of the audiences $37.5 \%$, the publication of activities on youtube media and publication articles in a journal.
\end{abstract}

Keywords: mental health; PSBB; COVID-19 pandemic

\section{Pendahuluan}

Akhir Desember 2019 dilaporkan adanya kasus pneumonia yang penyebabnya tidak diketahui. Kasus ini muncul pertama kali di Hubei, China. Penyakit tersebut akhirnya diberi nama coronavirus disease 2019 (COVID-19) dan disebabkan oleh virus jenis baru bernama SARS-CoV-2. (1) Di Indonesia, kasus terkonfirmasi pertama di bulan Maret 2020 dan bergerak fluktuatif sampai saat ini. Hingga Januari 2020, kasus konfirmasi per tanggal 14 Januari 2020 mencapai 869.600 kasus. (2)

Langkah awal penanganan COVID-19 di Indonesia berupa kebijakan pembatasan sosial berskala besar, termasuk didalamnya penguatan kebijakan physical distancing, memakai masker saat berada di ruang publik, dan mencuci 
tangan sesering mungkin ketika tangan dirasa kotor. (3)

Gangguan mental emosional dapat terjadi karena pandemi COVID-19. Kondisi ini memberi dampak pada kesehatan fisik maupun psikologis bagi setiap individu. Mayarakat harus tinggal di rumah dan membatasi aktivitas sosial di luar rumah. (4) Stress yang muncul selama masa pandemik COVID-19 dapat berupa ketakutan dan kecemasan mengenai kesehatan diri maupun kesehatan orang lain yang disayangi, perubahan pola tidur dan pola makan, dan memperberat kondisi pada pasien dengan penyakit kronis.(5)

Kecemasan biasanya berasal dari persepsi terhadap peristiwa yang tidak terkendali (uncontrolled), sehingga individu akan berfokus pada tindakan yang terkendali. (6)

Di Indonesia sendiri, kekhawatiran dan kecemasan masyarakat sangat tersirat dengan jelas. Terlebih ketika awal - awal kedatangan virus Corona ke Indonesia yang menjadikan berbagai kegiatan lumpuh sementara. (7)

Kesehatan mental menurut seorang ahli kesehatan Merriam Webster, merupakan suatu keadaan emosional dan psikologis yang baik, dimana individu dapat memanfaatkan kemampuan kognisi dan emosi, berfungsi dalam komunitasnya, dan memenuhi kebutuhan hidupnya sehari - hari. Pribadi yang normal/bermental sehat adalah pribadi yang menampilkan tingkah laku yang adekuat dan bisa diterima masyarakat pada umumnya, sikap hidupnya sesuai norma dan pola kelompok masyarakat, sehingga ada relasi interpersonal dan intersosial yang memuaskan. (8)

Menyikapi fenomena di atas, tim pengabdian melakukan seminar online. Kegiatan ini dilaksanakan sebagai sarana pemberian informasi tentang cara menjaga kesehatan mental keluarga selama pembatasan sosial berskala besar (PSBB).

\section{Metode}

Kegiatan abdimas dilaksanakan pada tanggal 20 Mei 2020 pukul 10 - 12 WIB melalui media CISCO WEBEX Meeting. Kegiatan ini diawali dengan pengurusan surat izin pelaksanaan kegiatan ke LP2M STIKes MERCUBAKTI JAYA Padang. Setelah itu, tim mengadakan briefing persiapan pelaksanaan kegiatan. Sehari sebelum kegiatan, tim mengadakan tes koneksi untuk memastikan tidak ada kendala pada aplikasi yang akan digunakan.

Dalam kegiatan ini, tim juga mengundang seorang narasumber Prima Aulia, M.Psi., Psikolog dari Universitas Negeri Padang sebagai pembicara. Pada pelaksanaan kegiatan, tim pengabdi melibatkan mahasiswa sebanyak tiga (3) orang. Mahasiswa bertugas sebagai fasilitator kegiatan, moderator, dan dokumentasi.

Pada kegiatan pembuka, dibagikan kuisioner tentang kondisi kesehatan mental peserta dan tingkat pengetahuan peserta tentang manajemen kesehatan mental. Kuisioner dibagikan kepada peserta melalui link google form.

Kuesioner ini berisi 10 item pernyataan mengenai kondisi kesehatan mental peserta dan 10 item pertanyaan multiple choices mengenai cara mengelola stress dimasa pandemi yang harus dijawab secara berurutan oleh peserta.

\section{Hasil dan Pembahasan}

Kegiatan abdimas diikuti oleh 24 orang peserta. Kegiatan berlangsung selama 120 menit 
dengan pembicara berjumlah tiga (3) orang.

Hasil dari pre test adalah sebagai berikut :

\begin{tabular}{|c|c|c|c|}
\hline No & $\begin{array}{c}\text { Kondisi kesehatan } \\
\text { mental }\end{array}$ & $\mathrm{Jml}$ & $\%$ \\
\hline 1 & Baik & 3 & 12.5 \\
\hline 2 & Sedang & 9 & 37.5 \\
\hline 3 & Buruk & 12 & 50 \\
\hline & Total & 24 & 100 \\
\hline
\end{tabular}

Dari tabel 1 tampak bahwa kondisi kesehatan mental audiens separuhnya $(50 \%)$ berada pada level buruk.

Tabel 2 Tingkat Pengetahuan Audiens tentang Kesehatan Mental Sebelum Penyuluhan

\begin{tabular}{clcc}
\hline No & $\begin{array}{c}\text { Pengetahuan tentang } \\
\text { kesehatan mental }\end{array}$ & $\mathrm{Jml}$ & $\%$ \\
\hline 1 & Tinggi & 9 & 37.5 \\
\hline 2 & Sedang & 10 & 41.7 \\
\hline 3 & Rendah & 5 & 20.8 \\
\hline
\end{tabular}

Tabel 2 menjelaskan bahwa tingkat pengetahuan audiens tentang kesehatan mental masih tergolong sedang dengan persentase $41.7 \%$.

Masalah kesehatan mental masih jarang dibicarakan di masyarakat sebab masih ada persepsi yang menyatakan bahwa kesehatan mental selalu memiliki konotasi negatif yaitu "sakit jiwa" atau "orang gila". Namun, setelah diberikan informasi dan edukasi tentang kesehatan mental pada kegiatan ini, terjadi peningkatan tingkat pengetahuan audiens dengan rincian sebagai berikut :
Tabel 3 Tingkat Pengetahuan Audiens tentang Kesehatan Mental Setelah Penyuluhan

\begin{tabular}{cccc}
\hline No & $\begin{array}{c}\text { Pengetahuan tentang } \\
\text { kesehatan mental }\end{array}$ & Jml & $\%$ \\
\hline 1 & Tinggi & 19 & 79.2 \\
\hline 2 & Sedang & 5 & 20.8 \\
\hline & Total & 24 & 100 \\
\hline
\end{tabular}

Dari tabel 3 terlihat tingkat pengetahuan audiens tentang kesehatan mental setelah penyuluhan meningkat sebesar $37.5 \%$. Kegiatan edukasi kesehatan dapat meningkatkan tingkat pengetahuan masyarakat.

Berikut adalah dokumentasi kegiatan:

Gambar 1. Moderator: Yulia Arifin, S.Si.T., M.Keb.

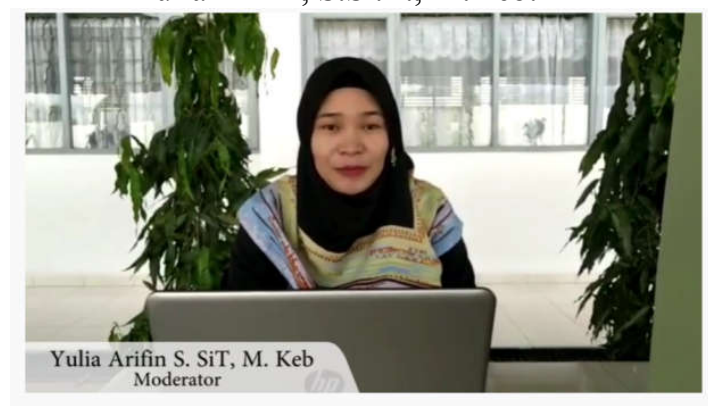

PARENTING TALK "MANAJEMEN STRESS ORANG TUA SAAT PANDEMI"

Gambar 2. Salah satu Panelis: Widya Zalmawita

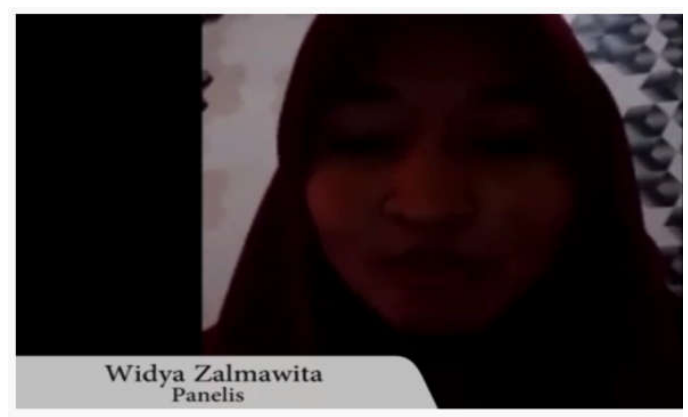

PARENTING TALK "MANAJEMEN STRESS ORANG TUA SAAT PANDEMI" 
Gambar 3. Narasumber:Prima Aulia, M.PSi., Psikolo

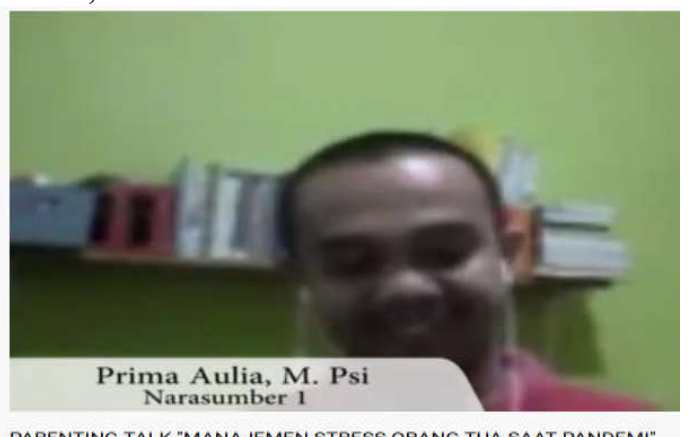

Gambar 4. Ketua Tim:

Dian Furwasyih, S.Keb., Bd., MSc

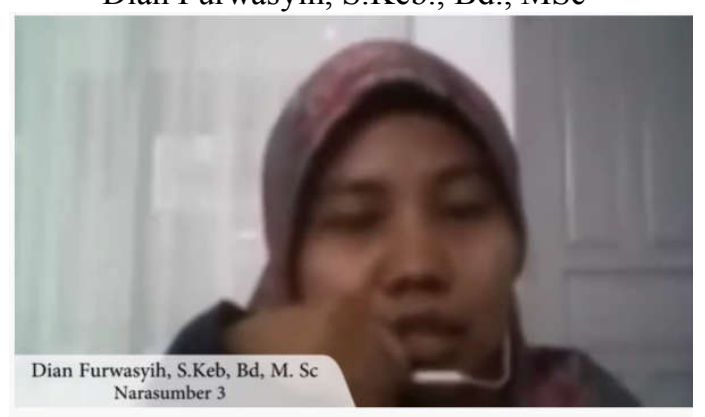

PARENTING TALK "MANAJEMEN STRESS ORANG TUA SAAT PANDEMI"

Gambar 3. Anggota Abdimas:

Sunesni, S.Si.T., M.Biomed

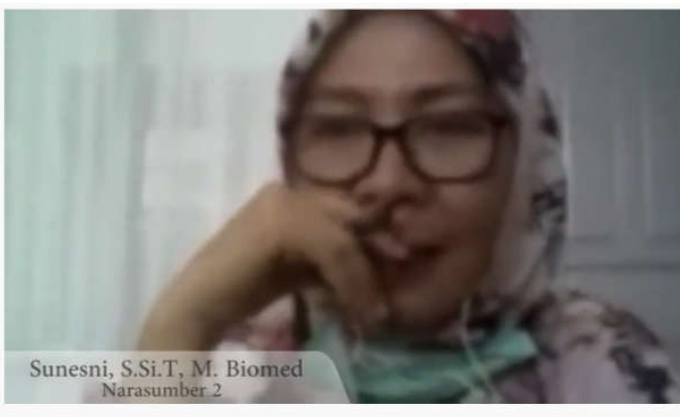

PARENTING TALK "MANAJEMEN STRESS ORANG TUA SAAT PANDEMI"

Gambar 4. Tangkapan layar kegiatan abdimas



4. Kesimpulan

Kegiatan ini memberikan dampak positif terhadap peningkatan pengetahuan audiens tentang kesehatan mental sebesar $37.5 \%$. Dapat direkomendasikan kepada audiens agar selalu melaksanakan anjuran yang telah disampaikan pada saat penyampaian materi dalam kegiatan ini tentang cara menjaga kesehatan mental, mengelola stress selama PSBB dimasa pandemi COVID-19 sehingga dapat terhindar dari perasaan ketakutan dan kekhawatiran berlebihan.

\section{Daftar Pustaka}

[1] Utomo AP. WHO Umumkan Nama Resmi untuk Virus Corona: COVID 19, 2020 [Online]. cited 2021 Jan 15. https://internasional.kompas.co $\mathrm{m} / \mathrm{read} / 2020 / 02 / 11 / 23170631 /$ who-umumkan-nama-resmiuntuk-virus-corona-covid-19

[2] Prasasti GD. 14 Januari 2021: Kasus Konfirmasi COVID-19 Bertambah 11.557, DKI Jakarta Laporkan 3.165, 2021. [Online]. cited 2021 Jan 15. https://www.liputan6.com/heal th/read/4457425/14-januari2021-kasus-konfirmasi-covid19-bertambah-11557-dkijakarta-laporkan-3165

[3] Wibowo A. Empat Strategi Pemerintah Atasi COVID-19, 2020. [Online] cited 2021 Jan 15. https://covid19.go.id/p/berita/e mpat-strategi-pemerintahatasi-covid-19

[4] Nurjanah S. Gangguan Mental Emosional Pada Klien Pandemi Covid 19 Di Rumah Karantina. J ilmu keperawatan jiwa. 3(3). pp.329-34, 2020. 
[5] World Health Organization (WHO). Mental Health During COVID-19 Pandemic, 2019.

[6] Shin K., Newman M. Self-And Other- Perceptions Of Interpersonal Problems: Effects Of Generalized Anxiety, Social Anxiety, And Depression. Anxiety Disorder. pp.1-10, 2019.

[7] Setyaningrum W, Yanuarita HA. Pengaruh Covid-19 Terhadap Kesehatan Mental Masyarakat Di Kota Malang. Ilmu Sos dan Pendidik. 4(4), pp.7. [Online] http://ejournal.mandalanursa.or g/index.php/JISIP/article/view/ 1580/1392

[8] Dewi KS. Buku Ajar Kesehatan Mental. UPT UNDIP Press Semarang. p.143, 2012. [Online] http://eprints.undip.ac.id/3884 0/1/KESEHATAN_MENTAL. pdf 